\title{
Krisen på hjemmefronten 1914-1918
}

- med Flensborg som eksempel

\section{af Michael Klos}

I årene 1914-18 rasede Den forste Verdenskrig. Krigen lagde et enormt pres på de krigsførende lande og deres befolkninger, og i november 1918 brød Tyskland sammen. Hvad gik forud? Hvordan reagerede befolkningen på krigens pres - og hvorfor kom det endelige sammenbrud? Cand. mag. Michael Klos, Århus, belyser her disse spørgsmål og kaster især lyset på forholdene i Flensborg.

\section{Indledning}

I august 1914 startede Den 1. Verdenskrig. I Tyskland talte soldaterne om en sommerudflugt til Paris. Officererne huskede krigen mod franskmændene i 1871, og soldaterne havde gennem deres opvækst hørt om dengang udførte heltegerninger. Det førte til en slags romantisering af krigen, og mange unge meldte sig frivilligt, for ikke at gå glip af krigen, der blev betragtet som en "stor oplevelse«.

Men denne krig blev anderledes. Den industrielle udvikling havde frembragt nye og bedre udviklede våbentyper. Prægtige rytterslag, som man kendte fra nationalromantiske malerier, blev erstattet af endeløse materialeslag og mudrede skyttegrave, som vi kender fra fotografier, bøger og film.

Den moderne krigsførelse krævede enorme menneskelige og materielle ressourcer, og krigen blev ikke afgjort af mændenes heltemod men af industriens og hjemmefrontens ydeevne. I august 1914 samledes nærmest hele den tyske befolkning bag den tyske kejser i kampen. Klassekampen blev lagt til side, og socialdemokraterne indgik en borgfred.

Jo længere krigen varede, jo tydeligere blev det dog, at denne borgfred var bygget på et svagt fundament. Presset på befolkningen og soldaterne voksede og nåede i november 1918 det punkt, hvor revolutionen brød ud. Det startede som en militærrevolte og smittede hurtigt af på arbejderklassen.

På de følgende sider skal der ses nærmere på krisen på hjemmefronten i Tyskland som helhed, hvorefter udviklingen i Flensborg undersøges nærmere. Der vil blive set nærmere på protestformerne og deres baggrund. Man har lige siden diskuteret, hvorfor folket og navnlig militæret gjorde oprør mod det kejserlige styre. 


\section{Hjemmefronten i Tyskland}

\section{Den sociale og politiske protest}

Betragter man udviklingen på den tyske hjemmefront 1914-18, kan man iagttage en gradvist voksende protest. Den kom til udtryk i forskellige former. Der var demonstrationer, strejker, deserteringer, plyndringer og andre former for »brud på den offentlige orden«.

Mens man for året 1914 kunne definere de protesterende 'masser' som udtryk for arbejderbevægelsens disciplinerede og organiserede medlemmer, var 'masserne' i 1918 blevet til en ukontrolleret størrelse med et modsætningsfyldt forhold til organisationerne. Man gennembrød partiets og fagforeningernes stramme aktionsrammer, i nogle tilfælde endda i direkte protest vendt mod den traditionelle ledelse. Den store strejkebølge $\mathrm{i}$ januar 1918 ramte flere byer og var organiseret uden om den samarbejdsvillige del af fagbevægelsen. Overfor denne form for organisation stod de spontane aktioner, som f.eks. udviklede sig i en ke foran bagerbutikken.

Det gjorde ikke sagen bedre, at myndighederne gentagne gange viste, at de ikke magtede at organisere markedet. Den førte prispolitik bevirkede, at mellem $30-50 \%$ af forbrugsvarerne blev omsat på det sorte marked. Statsmagten var selv involveret $\mathrm{i}$ illegal import, mens man prøvede at stoppe industriens. Problemet blev løst ved at gøre en ulovlig handling lovlig. ${ }^{1}$

I løbet af verdenskrigen blev fire protestmotiver tydelige: ${ }^{2}$

1. Utilfredshed med den økonomiske situation.

2. Fredslængsel og krigslede.

3. Social protest.

4. Politisk protest.

Selvom man finder eksempler på f.eks. rent politisk motiverede protester, så var de fleste domineret af ét hovedtema. I militærets stemningsrapporter kommer det gang på gang tydeligt frem, at hovedårsagen til protesten eller uroen var mangelen på forsyning med fodevarer, dels en absolut knaphed på madvarer, der førte til at folk sultede, dels misforhold i fordelingen af forsyningerne, som medførte en fornemmelse af at være blevet behandlet uretfærdigt. ${ }^{3}$

For juni 1917 kunne det IX. armékorps' generalkommando i Altona i sin rapport om stemningen skrive, at majsolen havde afspændt situationen og dernæst hed det: "Hos det store flertal i folket er stemningen et mavespørgsmål ...«. ${ }^{4}$

Den politiske protest koncentrerede sig om to hovedemner, nemlig politiske reformer og fra 1917 »fred uden anneksioner«. Begge krav var fremme, da novemberrevolutionen i 1918 startede. 


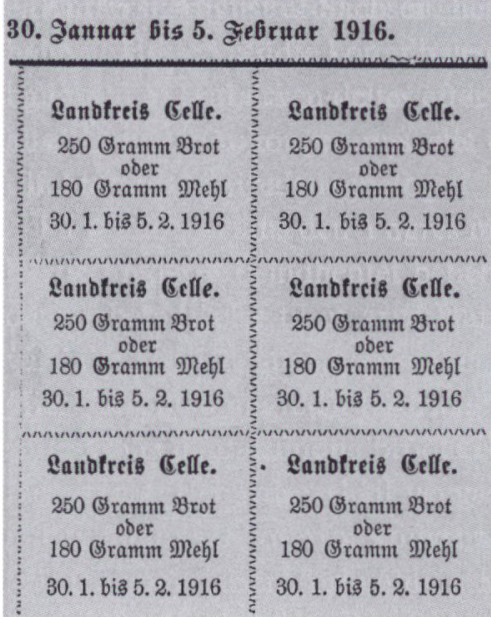

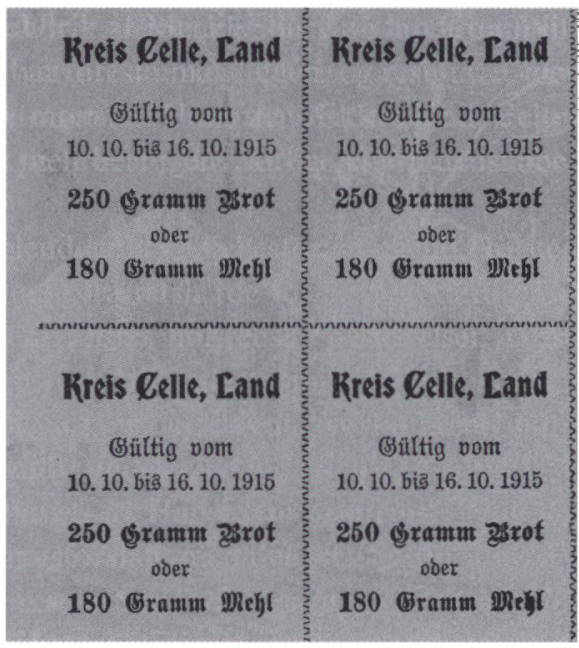

Rationering satte sit prag på dagligdagen $i$ Tyskland under det meste af 1. Verdenskrig. Her rationeringsmarker fra Landkreis Celle 1915-16. Arkivet ved Dansk Centralbibliotek for Sydslesvig. D b 19.

\section{Protestens udformning 1916-17}

I august 1914 indgik de tyske arbejderledere en borgfred for at hjælpe fædrelandet $\mathrm{i}$ det, de kaldte "farens stund «. Med denne handling håbede flere førende socialdemokrater endelig at opnå national anerkendelse. Man gik ud fra, at krigen ville ende med en sejr.

Men den indre fred varede kun kort, og med den tiltagende forværring af forholdene brast visionen om borgfreden. Allerede i 1915 finder man eksempler på protester og uroligheder. Kriminalstatistikken for perioden 1912-17 viser følgende interessante udvikling i opgivelserne over domme i anklager; 'mod staten, offentlig orden og religionen':

Tabel $1^{5}$

\begin{tabular}{rc|c|cl|l}
\hline & Demte & Mand & Kvinder $i \%$ & Unge 12-18 dr \\
\hline 1912 & 105.999 & 88.528 & 15.228 & 14 & 2.243 \\
1914 & 84.423 & 68.910 & 13.607 & 16 & 1.906 \\
1915 & 179.447 & 121.001 & 50.817 & 28 & 7.629 \\
1916 & 81.614 & 41.678 & 36.736 & 45 & 3.200 \\
1917 & 86.146 & 43.078 & 39.100 & 45 & 3.968 \\
\hline
\end{tabular}

Selvom disse tal skal betragtes med et vist forbehold, kan de blandt andet bruges til at illustrere kvindernes øgede 'aktivitet' på gaden. I løbet af krigen blev antallet af dømte kvinder mere end fordoblet. De unge viser ligeledes en 
stigende aktivitet, der dog er mindre markant end kvindernes. Tabellen er med til at underbygge den almindelige opfattelse, at aktionerne på gaderne blev domineret af kvinder og unge - set i forhold til fredstiden.

Udover de svært overskuelige og ofte lokalt begrænsede spontane aktioner medførte udviklingen tre større protestbølger fordelt på årene 1916, $1917 \mathrm{og}$ 1918.

\section{Uroen $i 1916$}

Arbejderbevægelsens traditionelle festdag den 1. maj skulle i 1916 markeres med en aktion i Berlin, hvor spartakisten Karl Liebknecht ville holde en tale. Han nåede lige at sige: »Ned med krigen, ned med regeringen!«, inden politiet arresterede ham.

Denne aktion og retssagen der fulgte efter, førte til en række sympatidemonstrationer og enkelte strejker i juni 1916 til fordel for den dømtes løsladelse. K. Liebknecht blev den 28. juni 1916 dømt til $2 \frac{1}{2}$ års tugthus, den 4 . november samme år $i$ anden instans til 4 år og én måned. Dommen $i$ juni 1916 udløste en lang række protestaktioner, der var under indflydelse af spartakusgruppen. ${ }^{6}$

\section{Aprilurolighederne 1917}

Vinteren 1916-17 er gået over i historien som 'kålroevinteren'. På grund af en forfejlet prispolitik havde landmændene dyrket kålroer fremfor kartofler. Oven i det havde vejret været dårligt, og høsten i Mellem- og Østeuropa var mager, men heldigvis havde man i Tyskland roerne som erstatning. Man fik nærmest roer morgen, middag og aften.

Den 15. april 1917 måtte regeringen dog sætte brødrationen yderligere ned. Det gjaldt også for de hårdtarbejdende grupper i krigsindustrien, som ellers fik ekstra rationer. Denne nedskæring set $\mathrm{i}$ lyset af den hårde kålroevinter dannede udgangspunkt for aprilstrejken. Strejkebevægelsen havde sine hovedcentre bl.a. i Leipzig og Berlin. I Berlin havde strejken den største opbakning, hvilket blandt andet hang sammen med, at omtrent $45 \%$ af arbejderne var fagligt organiserede. Her demonstrerede omkring 217.000 arbejdere. $^{7}$

I Leipzig fik bevægelsen udover de materielle krav en politisk undertone inspireret af udviklingen i Rusland. Man fremsatte kravet om 'fred uden anneksioner', ophævelse af censuren, løsladelse af politiske fanger m.m. Disse krav fik navnet 'Leipziger Program'. ${ }^{8}$

Allerede den 18. april havde de strejkende i Berlin overtaget dette programs punkter. Protesten fik dermed en klar politisk dimension, og konsekvenserne lod ikke vente på sig. Nogle af de mest aktive agitatorer blev nærmest omgående indkaldt til fronten. Fabrikkerne "Deutsche Waffen- und Munitionsfabriken« blev sat under militær kontrol, efter at forhandlingerne var brudt sam- 
men. Militærforvaltningen opfordrede arbejderne til at genoptage arbejdet under trussel om straf! Den 23. april var arbejdet genoptaget.

Selvom den tyske ledelse forsøgte at forhindre konflikterne på arbejdsmarkedet, var de en kendsgerning under hele krigen. Man kan således se en tiltagende strejkeaktivitet, der kulminerede i slutningen af krigen.

Tabel 2.9 Strejke- og lock-out udviklingen 1913-18

\begin{tabular}{lll|ll}
\hline & \multicolumn{2}{l|}{ Strejker } & Lock-outs \\
\cline { 2 - 5 } & Antal & Strejkende i 1000 & Antal & Ramte i 1000 \\
\hline 1913 & 2.127 & 266 & 337 & 57 \\
1914 & 1.115 & 61 & 108 & 37 \\
1915 & 137 & 14 & 4 & 1 \\
1916 & 240 & 129 & - & \\
1917 & 561 & 667 & 1 & 1 \\
$1918^{10}$ & $531 / 773$ & 391 & 1 & 0 \\
\hline
\end{tabular}

Antal deltagere: højeste antal strejkende/lock out ramte på samme tid i konflikten).

Tabel 2 viser tre interessante udviklinger.

1. Antallet af strejker, set i forhold til fredstiden er lav, mens 2. antallet af strejkende i hvert enkelt tilfalde er stort i forhold til fredstiden. 3. Lock-out'en er nærmest gået af brug, som en følge af krigen.

De to første punkter kan illustrere, at de små virksomheder og mindre konflikter blev færre bl.a. på grund af lukningen af de små virksomheder. Det stigende antal strejkende er udtryk for en tiltagende opbakning af strejken, men ligeledes for, at arbejderkoncentrationen og dermed antallet af potentielle strejkende i enkelte fabrikker voksede. Indenfor de store virksomheder, som f.eks. Krupp i Essen, der i 1913 havde 39.000 og i 1918106.000 ansatte, kunne arbejderne bedre 'gemme sig' end i de små virksomheder, hvor alle kendte alle.

Forud for aprilstrejken i 1917 var der omfattende forsyningsuroligheder i forskellige dele af landet. De fleste var opstået spontant. For at undgå dem var det for myndighederne vigtigt at kanalisere de spontane og ukontrollerede aktioner ind i kontrollerbare baner oftest ved hjælp af de moderate dele af arbejderbevægelsen. ${ }^{11}$

Myndighederne var blevet klar over, at fagforeningerne var de bedst egnede til at holde masserne i ro. Derfor blev de lokale myndigheder opfordret til at tage kontakt med de moderate dele af fagbevægelsen og socialdemokratiet; de radikale arbejdere skulle sendes til skyttegravene. ${ }^{12}$

Efter de voldsomme uroligheder i januar 1918 forfattede indenrigsministeren, Bill Arnold Drews, et memorandum om den indenrigspolitiske situation. Denne rapport affødte flere reaktioner, blandt andet fra selveste Hindenburg, lederen af den militære overkommando. Mens Drews i sin redegørelse 
kom med en kritisk og realistisk vurdering af forholdene, kommenterede den militære overkommanderende Hindenburg rapporten negativt uden sans for den vanskelige situation Tyskland befandt sig $i$.

Ministeren frygtede nye uroligheder, hvis krigen fortsatte meget længere. Hindenburg derimod mente at folket, bortset fra en lille gruppe lediggængere og en del af den jødiske og socialdemokratiske presse, stod bag regeringens krigsmål. Han talte om en "god fred med erobringer og krigsskadeserstatninger«.

Vedrørende politiske reformer mente Drews, at de var uundgåelige. Hindenburg mente derimod efter bedste aristokratiske overbevisning, at det tyske folk og navnlig Preussens ikke var modent til den almene lighed. Det var et folk der var vant til orden og autoritet, takket være sin høje moralske og åndelige styrke. Han fortsatte med at slå fast, at der til dato ikke havde været tegn på politiske strejker, januarstrejken var en undtagelse. Der blev sat lighedstegn mellem frontsoldaterne og 'dem derhjemme', og de skulle ledes på samme måde: "... nemlig gennem en stærk hånd, og strengeste retfærdighed overfor alle ...... ${ }^{13}$

\section{Januarstrejken 1918}

Årsskiftet 1917-18 markerede på mange måder en rakke vigtige begivenheder. I november 1917 overtog bolsjevikkerne revolutionen i Rusland. Lenin tilbød fred, og der indledtes forhandlinger i Brest-Litowsk. Som en slags modtræk til Lenins udspil lancerede den amerikanske præsident Woodrow Wilson den 8. januar 1918 de berømte ' 14 punkter'. Et liberalt fredsprogram, der bl.a. talte om nationernes selvbestemmelsesret, frihed og retfærdighed.

I mellemtiden begyndte centralmagterne at stille krav til fredsforhandlingerne i Brest-Litowsk, der trak i langdrag. Den 14. januar startede voldsomme uroligheder i Østrig-Ungarn. Wien, Budapest og Prag blev centre for omfattende strejker vendt mod de træge forhandlinger i Brest-Litowsk, mod sult og krigen. I Tyskland offentliggjorde Spartakusgruppen i slutningen af januar 1918 et opråb til strejke under henvisning til blandt andet begivenhederne $i$ Østrig-Ungarn.

Efter den tredje jul i krigens tegn, var menneskene ved at være trætte og slidt op. Den 28. januar startede den mest omfattende strejkebevægelse, som Tyskland havde været udsat for i løbet af krigen. I Berlin var det de velorganiserede revolutionære Obleute (tillidsmænd), der var med til at planlægge aktionerne. Men man må ikke overvurdere disses indflydelse. Mange politiske (radikale) ledere var på dette tidspunkt i politiets hænder. Pressen var censureret, agitationsmulighederne var ikke de bedste. På trods af dette strejkede alene i Berlin omkring 400.000 arbejdere den første strejkedag. Specielt metal- 
arbejderne udviste en stor aktivitet. I hele riget var der omkring en million strejkende. Dette tal viser, at det ikke kun var de politisk radikale mindretal, der strejkede, det var tværtimod en bred bevægelse. Man krævede fred, mad og frihed. ${ }^{14} \mathrm{Krav}$, som også flertalssocialdemokratiets tilhængere havde basale interesser $i$ at få opfyldt. Kravet om en revolutionær omvæltning var ikke massernes krav, men et krav som det politisk radikale mindretal repræsenterede.

Bevægelsen var $\mathrm{i}$ høj grad præget af spontanitet. Da fagbevægelsen ikke ville støtte strejken, måtte de strejkende organisere sig uden om de eksisterende organer. Man valgte tillidsmænd, der i højere grad var uafhængige af den traditionelle fagbevægelses ledelse. For at kunne vurdere januarstrejkens omfang og betydning må man huske, under hvilke forhold den udviklede sig: Belejringsloven, censur, militarisering og andre repressalier gjorde det farligt at deltage $i$ aktionerne. Alene $i$ Berlin blev som en følge af strejken 50.000 deltagere indkaldt til militæret og 7 virksomheder sat under militær administration. ${ }^{15}$ Ikke alle, der var utilfredse med situationen, turde udsætte sig for disse farer og blev derfor hjemme.

Historikeren E. Lucas gør opmærksom på, at en del af de strejkende var af den overbevisning, at krigen kunne afsluttes med en strejke. Derfor var man efter januar 1918 gået $\mathrm{i}$ gang med at udbygge et kontaktnet til provinsen. Man ville på denne måde give 'den næste strejke' en endnu større bredde og effektivitet. Men disse planer blev overhalet af begivenhederne i november 1918 - begivenheder, som de revolutionære aktivister ikke havde forudset. Det var matroserne fra den kejserlige marine i Kiel, der startede den revolutionære bevægelse og ikke arbejderne ... ${ }^{16}$

Teologen Ernst Troeltsch beskrev udviklingen i slutningen af december 1918 med følgende rammende ord: "Revolutionen var frem for alt en militærrevolution, den blussede op på vidt forskellige steder ved fronten og hjemme. Forløbet var over alt det samme: et sammenbrud uden kamp, officererne forsvandt, soldaterrådene herskede og alt var hulter til bulter, medens soldaterne og matroserne i forste omgang kun udtrykte deres glæde over freden. « ${ }^{17}$

\section{Udviklingen i Flensborg}

Flensborg var og er geografisk placeret i Tysklands periferi. Under verdenskrigen fik det stor betydning for byens økonomiske udvikling. Krigen lagde beslag på de deltagende landes største anstrengelser. Man måtte koncentrere sine kræfter, og det gik ud over Tysklands randområder. Som en følge af krigen mistede Tyskland i perioden 1913-18 lidt over 10\% af sin numeriske arbejds- 
kraft. Kvinder, unge, krigsfanger og såkaldt reklamerede erstattede de indkaldte mænd i den krigsvigtige produktion. Flensborg mistede i tidsrummet 1907 til $191741 \%$ af sin arbejdsstyrke. ${ }^{18}$ Byens største arbejdsgiver værftet, mistede i løbet af få måneder over halvdelen af sin arbejdsstyrke. Det førte til, at handelskammeret i Flensborg den 20. november 1914 skrev til regeringspræsidenten i Slesvig, at flere indkaldelser højst sandsynligt ville medføre en lukning af værftet, hvilket ville få meget alvorlige følger for byen. Byens magistrat fulgte sagen op med en rapport, der nåede til den samme konklusion. ${ }^{19}$ Resultatet blev, at værftet krigen igennem havde mellem $900-950$ arbejdere beskæftiget - i 1911 havde tallet været 2.900 .

\section{Borgfreden i Flensborg 1914}

Den 27. juli 1914 opfordrede den socialdemokratiske avis 'Flensburger Volkszeitung' de flensborgske arbejdere til at protestere mod krigstruslen. Det var udtryk for en støtte til de tyske modforholdsregler. Den følgende dag var der omtrent 3.000 deltagere til demonstration med efterfølgende møde i fagforeningshuset.

Nærmest symptomatisk for den socialdemokratiske ledelses holdning til krigen var en tale, som redaktøren for "Schleswig-Holsteinische Volkszeitung«, Eduard Adler, holdt i Flensborg til støtte for den tyske krigsindsats. Skolelæreren $\mathbf{H}$. Schröder fra Flensborg noterede i sin dagbog følgende om talen: $" . .$. Han talte med stor patriotisk alvor om den gevaldige fare, som truer os .... ${ }^{20}$

Borgfreden i Flensborg var en kendsgerning, og den 18. august 1914 modtog byens magistrat en petition fra arbejderbevægelsen, hvor man højtideligt lovede og tilbød samarbejde.

Mens de unge arbejdere forlod byen som soldater eller som arbejdere til industrier sydpå, blev de ældre tilbage. Ud af 5 SPD byrådsmedlemmer fra før krigen, var der kun to tilbage, de andre var blevet indkaldt. Disse to var Waldemar Sörensen og Peter Michelsen. Flensborgs overborgmester skrev i april 1917 til regeringspræsidenten i Slesvig om det glimrende samarbejde, der herskede mellem arbejderbevægelsens ledere og byens forvaltning. I forbindelse med optræk til uro, som i følge regeringspræsidenten i regelen skete p.g.a. misforståelser, var det gentagne gange lykkedes for arbejderlederne at få sikret den offentlige orden. Han sluttede med følgende ord: "Maduroligheder har ikke fundet sted her «. ${ }^{21}$

Denne beretning gav dog ikke et dækkende billede af forholdene. Lidt over en uge senere skrev politiforvaltningen i Flensborg til generalkommandoen i Altona om stemningen $\mathrm{i}$ befolkningen. Her gjorde man opmærksom på, at der herskede en udbredt uvilje $i$ befolkningen. Man var meget utilfreds med myndighedernes manglende evne til at forsyne befolkningen med fødevarer. ${ }^{22}$ 
Typograf Waldemar Sorensen var socialdemokratisk medlem af Flensborg byrdd 1918 og $i$ afstemningstiden konstitueret politimester. Han sluttede sig til den danske side. Foto i Dansk Centralbibliotek for Sydslesvig.

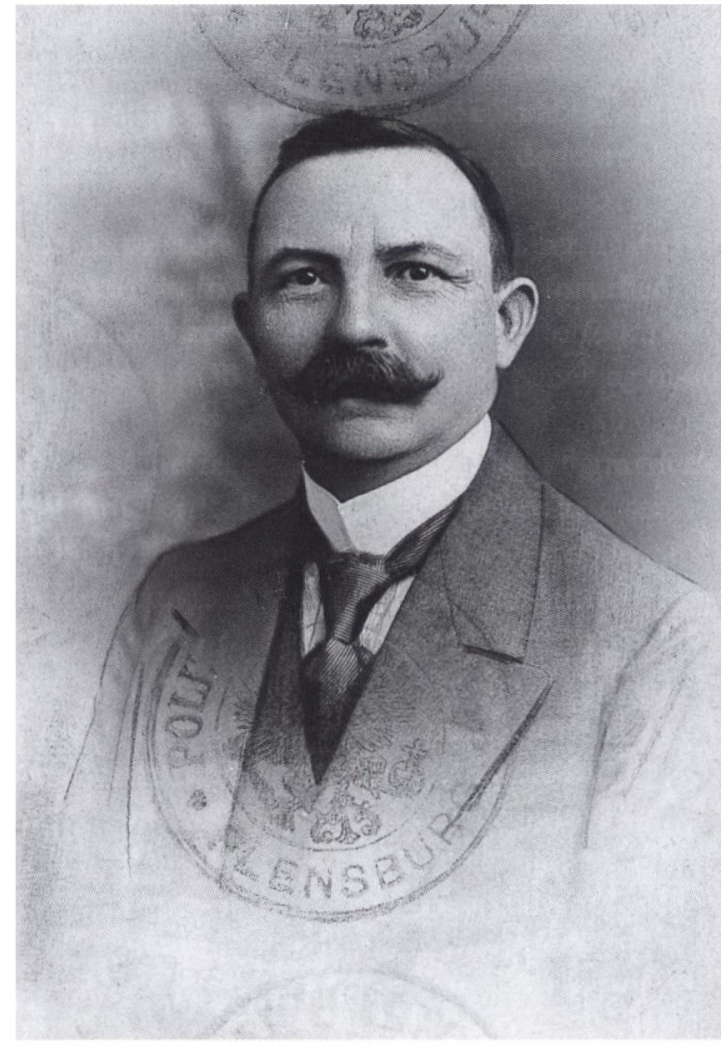

Myndighederne regnede dog ikke direkte med uroligheder i byen. Blandt andet fordi det politiske klima var uden de store spændinger. Byens socialdemokrater tilhørte i høj grad flertalssocialdemokratiet (MSPD) og var meget moderate. Et stående argument overfor de utilfredse var, at byens befolkning havde det godt $\mathrm{i}$ forhold til storbyerne eller soldaterne ved fronten, og at det derfor ikke var opportunt at klage.

\section{Urolighederne i 1917}

Borgmesteren havde ret, da han i april 1917 kunne sige, at der endnu ikke havde været maduroligheder. Men det var ikke ensbetydende med, at alt var idyl i Flensborg. Allerede i 1915 rejste sig stemmer i arbejderkredse, der udtrykte utilfredshed med situationen. F.eks. holdt arbejderne fra værftet, som ifølge "Flensburger Volkszeitung" var overvejende ældre, et møde, hvor man diskuterede løn- og prisudviklingen. Det blev dog understreget, at der ikke var ønske om at bryde 'borgfreden'! ${ }^{33}$ 
I marts 1917 var der flere gange arbejdergrupper, som mødte op på rådhuset for at kræve større madrationer. ${ }^{24}$ Det fik myndighederne til at reagere. De skrev til de enkelte virksomheder og fagforeningen og bad om en forklaring. Det viste sig specielt at være arbejderne fra værftet, der forlod arbejdspladsen til fordel for besøget på rådhuset. Lederen af fagforeningskartellet P. Diez svarede, at han ikke var indforstået med aktionen, men at han havde forståelse for den, idet der var flere begrundede kritikpunkter. Han gjorde ligeledes opmærksom på, at det kun førte til yderligere uro, hvis embedsmændene truede med at sætte politiet ind. ${ }^{25}$

Et centralt kritikpunkt vedrørte arbejdernes inddeling i "Schwer-« og "Schwerst-« arbejdende. De hårdest arbejdende fik ekstra madrationer, da man gik ud fra, at de havde en større forbrænding og dermed et øget energibehov. Arbejdede man i rustningsindustrien, fik man ligeledes ekstrarationer. De lokale myndigheder, fagforeningen og virksomhederne måtte føre en omfattende korrespondance med regeringspræsidenten i Slesvig om disse spørgsmål. F.eks. skrev fabriksinspektøren den 8. marts 1917 til regeringspræsidenten, at han havde modtaget en delegation af værftarbejdere, som havde klaget over det uretfærdige, der lå i, at arbejdere på værftet, som arbejdede med 'Dockbau', fik ekstraration som rustningsarbejdere, mens de andre ikke fik det! Det var uretfærdigt, mente inspektøren og anbefalede overfor regeringspræsidenten, at alle hårdtarbejdende værftarbejdere skulle anerkendes som arbejdere $\mathrm{i}$ rustningsindustrien. ${ }^{26}$

Svaret kom den 6. april, og det blev negativt. ${ }^{27}$ Det førte til en klage fra P. Michelsen, lederen af arbejdersekretariatet og byrådsmedlem, som den 26. marts 1917 skrev til »Kgl. Preussische Landes Getreide Amt/Berlin«, vedrørende den uretfærdige forskelsbehandling mellem »Schwer-« og »Schwerst-« arbejdende. Han gjorde opmærksom på, at arbejderne var meget utilfredse og allerede flere gange havde besøgt rådhuset for at markere deres utilfredshed.

I krigsproduktionen var der generelt 2-3 timer's overarbejde dagligt. Højtkvalificerede arbejdere på værftet og $\mathrm{i}$ den metalforarbejdende industri arbejdede op til 15 timer om dagen. Bl.a. fordi warbejdet i stort omfang udføres af ikke faglærte arbejdere, lærlinge og krigsfanger $«{ }^{28} \mathrm{P}$. Michelsen gjorde opmærksom på den store belastning, og at det var vanskeligt at forklare forskelsbehandlingen overfor de klagende arbejdere. Berlin svarede, at klagen var berettiget, men så længe de nye regler ikke var færdige, skulle man fortsætte efter de gamle. ${ }^{29}$

I april 1917 kunne Flensborg Avis flere gange meddele, at unge mennekser havde begået hærværk. Den 17. april blev ruderne i en bagerbutik knust og et brød stjålet. ${ }^{30}$

De nævnte eksempler gør det tydeligt, at borgmesterens rapport fra april 
havde givet et forvansket billede. Den var skrevet i en tid, hvor arbejderne var meget utilfredse med forholdene, men følte sig bundet af borgfreden.

I juli og september 1917 kom disse vanskeligheder klart frem til overfladen. Den 13. juli provede specielt "weibliche und jugendliche Personen « at organisere brød - man plyndrede bagerbutikkerne. Flensborgs store brødfabrik 'Viktoria' blev plyndret af mellem 2-3.000 mennesker. I alt blev der taget 9.087 brød uden rationeringskort og 3.062 uden betaling. Politiet stod magtesløst, og det tilkaldte militær kom alt for sent. Myndighederne var tydeligvis blevet overrumplet af begivenhederne.

Disse oplysninger er samlet sammen på basis af bagernes egne oplysninger. Politimyndigheden mente, at bagerne overdrev en del i deres opgivelser. Alt i alt blev der ført undersøgelser i mellem 40-50 sager. ${ }^{31}$ Myndighederne var meget opsatte på at opklare sagerne og straffe de skyldige. Indehaverne og sælgerne $\mathrm{i}$ bagerbutikkerne blev presset til at angive navne, hvilket de ikke var

Rationeringskort for kartofler fra Flensborg oktober 1917. Gengivet efter Britta Nicolai: Die Lebensmittelversorgung in Flensburg 1914-18 (1988).

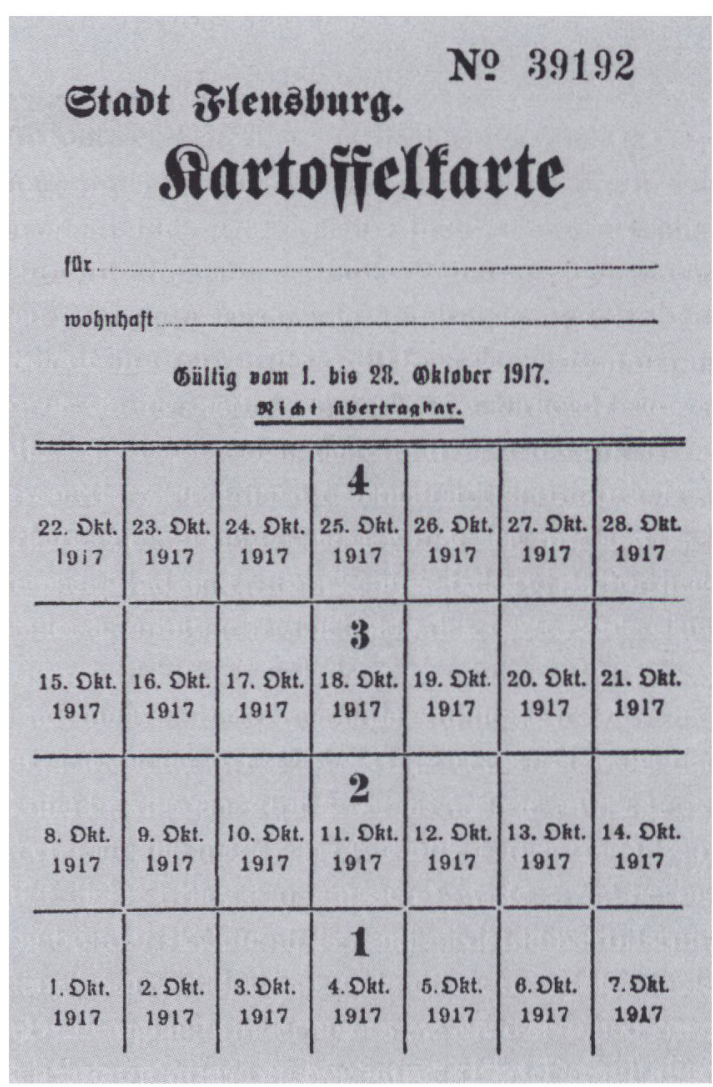


særlig villige til. ${ }^{32}$ Selvom man fik oplyst en række navne, forblev størstedelen af sagerne uopklaret.

For at forbedre stemningen i befolkningen tilbød man kartofler i stedet for brød, men situationen var stadigvæk spændt. Den 25. juli var der igen optræk til demonstrationer. $\mathrm{Nu}$ var myndighederne dog forberedte, og militæret var sat i beredskab, så man kunne sprede uromagerne, som hovedsaglig var kvinder. Misstemningen i Flensborg havde de samme årsager som i resten af riget; forfejlet prispolitik, ulig fordeling og mangel på alt.

I en politirapport fra den 9. august 1917 gives der udtryk for nervøsitet overfor den manglende kulforsyning kombineret med de utilstrakkelige forsyninger af fødevarer. De to »alten, altbewährten Führer der alten sozialdemokratischen Partei ...« Waldemar Sörensen og Peter Michelsen udtrykte bekymring. Man forudså, at den kommende vinter uden tilstrækkeligt med kul og mad ville føre til voldsomme protester. Protesten ville specielt komme fra de lavere sociale lag, som ikke kunne købe på det sorte marked. Men udover denne samfundsgruppe nævner rapporten militæret som mulig kilde til uro. Rapporten afsluttes med, at frem til den 13. juli har Flensborg varet en rolig by, men nu ser man med stor bekymring på den kommende vinter. ${ }^{33}$

Den udtrykte skepsis var ikke ubegrundet. Allerede én måned senere var der atter uro i gaderne. Politiforvaltningen sendte et telegram til regeringspræsidenten, hvoraf det fremgår, at flere hundrede mennesker fredag den 14. september forsamlede sig foran bagerbutikker og rådhuset. Man krævede brød! Det hele startede kl. 13, militæret greb ind kl. 16 og om aftenen var roen genoprettet. ${ }^{34}$

I følge den mere udførlige politirapport af den 15. september 1917 til generalkommandoen skete der følgende: Omkring kl. 10 var der tegn til opløb foran 4 bagerbutikker $i$ arbejderkvarteret $i$ den nordlige bydel. Folk ville have brød uden at aflevere brødmærker - de fik intet i denne omgang. Det hele fortsatte frem til kl. $12.00 \mathrm{og}$ var på dette tidspunkt under politiets kontrol. De mindre opløb kunne splittes af politiet.

Kl. 12.45 fik politiet melding om, at ca. 30-40 kvinder var mødt op ved det gamle værft i den nordlige bydel, men også denne gruppe blev opløst. Kort tid efter drog mindre grupper af kvinder og unge fra den nordlige bydel igennem byen, forbi rådhuset til et større bageri i den sydlige del af byen. Her krævede man ligeledes brød uden aflevering af mærker. Også her fik politiet hurtigt kontrol med uromagerne. Omtrent samtidig begyndte situationen at eskalere foran Rerups store brødfabrik. Hurtigt var der over 500 mennesker. Politiet var magtesløst, nogle betjente fik endda slået deres hjelme af hovedet. Hvilket man anså som en grov forseelse.

K1. 14.00 bad man militæret om hjælp (100 mand). Imellemtiden blev der 
kastet med sten fra mængden. Nu var der mellem 800-900 mennesker. For at få bagerbutikkens indgang fri, trak 7 politibetjente sablen! De blev dog ikke anvendt. I løbet af eftermiddagen kom militæret. De oprindelige 100 mand blev forstærket med yderligere 150 mand, idet urolighederne nu havde bredt sig til 10-12 steder over hele byen. Henimod aftenen var roen genoprettet.

I alt blev 11 mennesker anholdt (5 kvinder, 4 »halbwüchsige Burschen «, I mandlig civilperson og 1 militærperson). Man bibeholdt nattepatruljen, og der blev sat ekstra vagter på særligt udsatte steder.

Som forklaring på disse uroligheder anførte rapporten, at de fattige i samfundet $\mathrm{i}$ den forgange uge ikke havde fåt udleveret grød, gryn eller andre varer fra mollerne. ${ }^{35}$

\section{Januarstrejken 1918}

I den følgende tid bredte strejkebevægelsen sig over hele riget. Slagordene; "Nieder mit dem Krieg! Nieder mit der Regierung! Frieden! Freiheit! Brot!«, samlede de utilfredse.

Frem til 1914 havde Flensborg været en by, hvor arbejderne ikke var bange for at tage kampen op mod kapitalen. Arbejdskampene var stoppet med krigen, og borgfreden dominerede forholdene. Også den store strejkebølge fra april 1917 gik forbi Flensborg, men til gengæld kom det som nævnt til maduroligheder i sommeren samme år. Hvordan ville de flensborgske arbejdere forholde sig overfor den strejkebølge, som derefter skyllede frem?

Politirapporten fra januar 1918 giver svaret. I rapporten fra den 29. januar 1918 stod:

- Flensborg: "Endnu alt roligt. Fra middag i dag strejke på værftet sandsynlig"

- Mürwik: »Arbejderne på torpedoværkstedet - omkring 100 mand strejker. $\ll^{36}$

I en mere udførlig rapport fra den 30. januar skrev politiforvaltningen blandt andet, at værftet, 'Anthon und Söhne' og 'N. Jepsen \& Sohn' var i fare for at blive ramt af strejken. Man havde gang i forhandlinger med de lokale arbejderførere, og der var begrundet håb om, at strejken i disse virksomheder var til at undgå. De strejkende på torpedoværkstedet og torpedoskydebanen 'Skorpion' i alt 140 mand, var ikke flensborgere! De var organiseret i Kiel og havde som alle andre "auswärts Streikenden, politische Ziele«. En arbejderleder fra Flensborg oplyste, at bevægelsen havde udspring i de uafhængige socialdemokrater (USPD), et parti som dog var uden betydning for Flensborg. Her var det gamle SPD afgørende. ${ }^{37}$ 
Den 31. januar lod general v. Falk følgende forördning offentliggøre i pressen:

»Alle Værnepligtige Arbejdstagere i disse Bedrifter, som har nedlagt Arbejdet, vil saafremt de ikke den 31. Januar om Morgenen til sædvanlig tid har genoptaget Arbejdet eller godtgjort, at de er arbejdsudygtige, blive indkaldt til hærtjeneste, og det vil blive dem tjenstelig befalet at genoptage det Arbejde, som de har nedlagt. De faar saa Soldaterløn og staar under Krigsloven. ${ }^{38}$

Stillet overfor denne trussel genoptog arbejderne produktionen, og den 4. februar kunne politiforvaltningen meddele regeringspræsidenten, at arbejderne i Flensborg havde genoptaget arbejdet »bedingungslos» den 1. februar: »Der Streik ist somit beendet. ( $^{39}$

\section{Rolige tider $i$ Flensborg?}

Et oplagt spørgsmål i forbindelse med strejkerne i Flensborg er: Hvorfor var det kun de udefra kommende arbejdere der strejkede og ikke flensborgerne? Svaret må på nuværende tidspunkt være hypotetisk. Det hjælper dog at vurdere problematikken i lyset af tre forhold; de materielle, strukturelle og politiske forhold i Flensborg.

Flensborgs administration formåede ifølge den omfattende analyse af B. Nicolai at løse mange problemer i forbindelse med forsyningssituationen. Et vigtigt led i forsyningen af befolkningen blev de såkaldte »Kriegsküchen«, dvs. madsteder, hvor man kunne købe billig middagsmad. I Flensborg blev der indrettet mellem 3-4 krigskøkkener i løbet af krigen. Gentagne ansøgninger om at få lov til at indrette et krigskøkken forbeholdt middelstanden blev afvist af byens magistrat. Man indrettede dog et særligt rum, hvor middelstanden kunne indtage måltiderne. I alt modtog omtrent $10 \%$ af byens befolkning mad fra krigskøkkenerne. ${ }^{40}$

Derudover havde byen et stort opland, hvor der var gode muligheder for illegal smughandel eller de såkaldte »Hamsterfahrten«. De flensborgske arbejdere og andre drev også et udbredt 'privat' havebrug, som blev til stor gavn under krigen. Byens magistrat skrev i november 1914 til regeringspræsidenten, at der ikke fandtes mange arbejdere med eget hus og have. Til gengæld var der flere hundrede, der havde en lille have, som var til gavn i vanskelige tider. ${ }^{41}$

Samtidig blev arbejdernes holdning til arbejdsnedlæggelser $i$ høj grad påvirket af de specielle strukturelle vanskeligheder, som rådede under krigen.

I løbet af krigen mistede Flensborg omkring $40 \%$ af sine arbejdere, hvilket bl.a. hang sammen med, at man placerede den krigsvigtige produktion i Tysklands centrum og ikke i yderområderne. 
Kiel, den 21. September 1917.

\author{
$A$ us $t \in 1,1$ un $g$ \\ der
}

Rilstungsbetrlebe im Rrelse Flensburg.

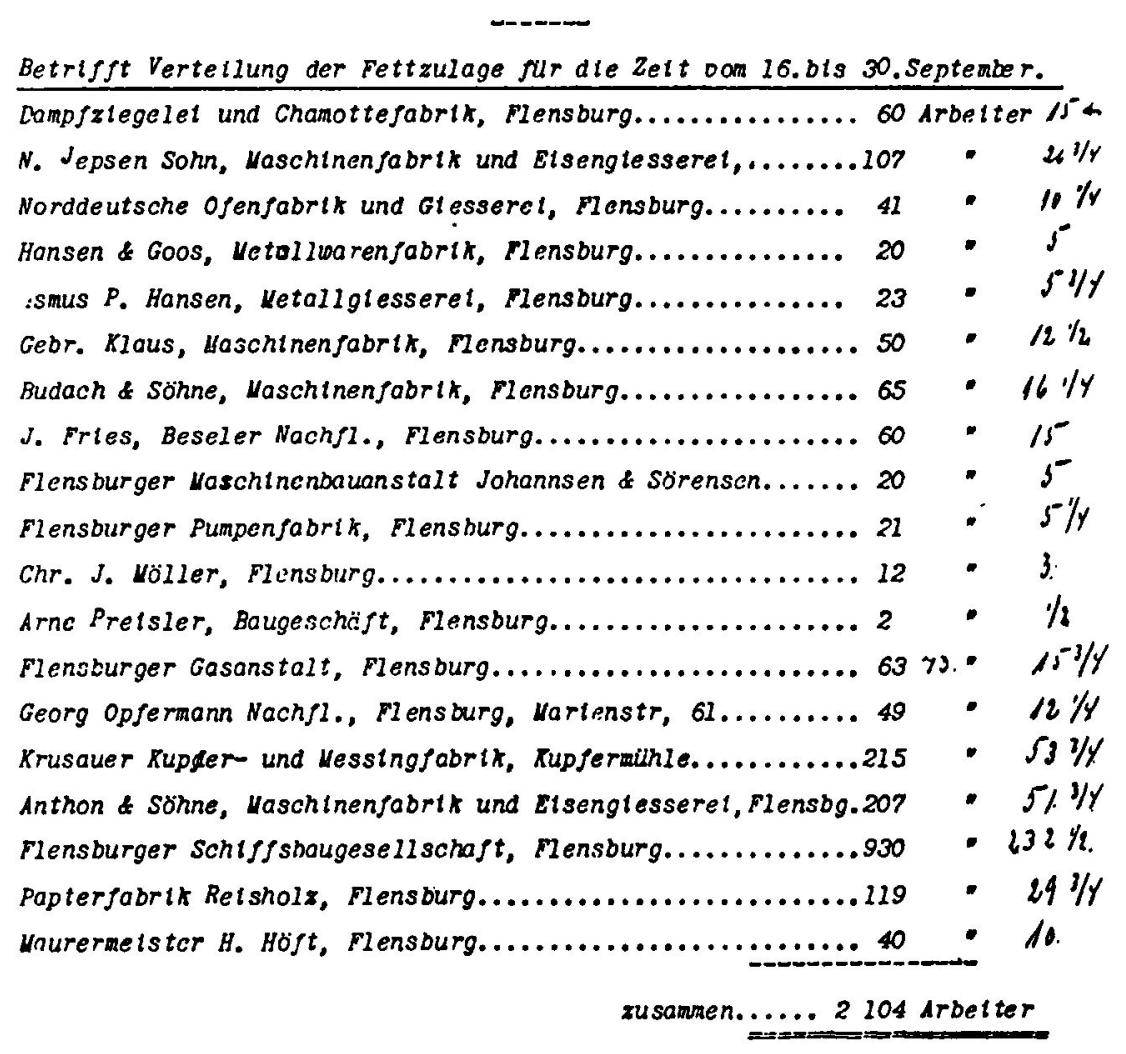

Arbejderne i krigsvigtige Flensborg-virksomheder fik sarrationer af levnedsmidler. Gengivet efter Michael Joho: Die Geschichte der Metallarbeiterbewegung und ihrer Gewerkschaften in Flensburg. Flensborg 1992 s. 254.

Gang på gang blev arbejdernes krav om forbedringer af løn- eller arbejdsforhold mødt med et nej under henvisning til den 'vanskelige tid', hvor konkurrencen om ordrerne var hård. En lønkamp ville være ensbetydende med ordretab eller endda lukning af virksomheden og dermed arbejdsløshed, flytning eller skyttegraven.

På et værftsarbejdermøde i september 1915 besluttede man f.eks. at bede 
om en form for dyrtidstillæg. Direktionen afviste det under henvisning til 'den vanskelige tid'. Værftets arbejdere troede på denne oplysning og regnede med, at værftets stilling ikke var alt for heldig. Kravene blev følgelig opgivet. ${ }^{42}$

Firmaet Jepsen \& Sohn måtte i starten af krigen som mange andre lukke p.g.a. manglen på arbejde, men genoptog virksomheden, efter at man havde aftalt en lønnedgang med arbejderne! ${ }^{43}$

Selvom arbejderne i Flensborg ikke var tilfredse med deres situation, affandt de sig således tilsyneladende med deres forhold. ${ }^{44}$

Før krigen ville arbejderne have 'kæmpet for deres ret', ligesom de havde gjort det $i$ den omfattende strejke i 1913. Men nu var situationen en anden. Efter arbejdskampen i 1913 var en del arbejdere taget fra byen. De dynamiske kræfter blandt arbejderne var enten ved fronten eller draget mod syd til de større industriområder. De rolige var blevet tilbage. Virksomhedernes størrelse muliggjorde en relativ effektiv overvågning, og politiet holdt skarpt øje med radikale - uden at finde nogen ekstreme elementer. Derudover manglede der en radikal politisk ledelse. Ledelsen såvel som partiets basis ville ikke bryde borgfreden i Flensborg.

De politiske forhold var således rolige i Flensborg. Indkaldelser, frafald og afvandringer førte til fald i arbejderbevægelsens medlemstal. Socialdemokratiet i Flensborg mistede i årene 1913-17 57\% af sine medlemmer, fagforeningskartellet mistede fra 1912 til $191666 \%$ af de organiserede arbejdere $4^{45}$

De tilbageblevne agitatorer var tydeligvis på linie med flertalssocialdemokraterne, og dannelsen af en USPD-gruppe i Flensborg blev først aktuel efter november 1918.

Den manglende politiske radikalitet kom til at præge revolutionens forløb i byen, da den endelig brød ud i november 1918. På baggrund af samtaler med de revolutionære ledere (Arbeiter- und Soldatenrat) kunne overborgmesteren den 8. november 1918 rapportere til regeringspræsidenten, at bevægelsens hovedformål var at få fred, og at bevægelsen ville ophøre, når denne var opnået. I Flensborg var arbejderlederne ikke bolsjevikker. ${ }^{46}$

De moderate socialdemokratiske ledere i Flensborg bibeholdt ledelsen og udgjorde arbejderrådet. Lederne for soldaterrådet blev betegnet som relativt upolitiske. Klassekampen foregik temmelig afdæmpet, og i stedet for fik det nationale spørgsmål meget hurtigt overtaget i den offentlige debat. Den dansksindede rigsdagsmand H. P. Hanssen havde den 23. oktober 1918 i rigsdagen krævet en folkeafstemning i de gamle danske områder. Det betød, at Flensborg, set med tyske øjne nu stod i fare for at blive dansk. En ny borgfred var derfor påkrævet. Arbejder- og soldaterrådet i Flensborg opfattede den nationale sag som vigtig og satte den over den sociale. Selvom man i SPD i starten bekendte sig til nationernes selvbestemmelsesret, var man ikke rede til at give 
slip på Flensborg. Det førte bl.a. til at den dansksindede Waldemar Sørensen blev udelukket fra SPD, da han erklærede, at han ville arbejde for Slesvigs genforening med Danmark. ${ }^{47}$

Sammenfattende må man således konkludere, at protesten i Flensborg i perioden 1914-18 i høj grad var upolitisk og ikke særlig radikal. Aktionerne opstod i reglen spontant i forlængelse af problemer med forsyningen af byens befolkning.

\section{Statsmagtens fallit}

Tyskland var i sommeren 1914 gået i krig med en forfejlet optimisme. Den uforudsete lange krig tydeliggjorde systemets svagheder. Disse svagheder trådte i baggrunden, sålænge rigets hære var på vej frem og succesmeldinger kunne pryde avisernes forsider. Vigtig for stemningen i folket var tilliden til statens ledelse, hvilket var gældende for både den militære og den civile side. Militærets stemningsrapporter bidrager med interessante iagttagelser til forståelsen af problemet. Gang på gang bliver der gjort opmærksom på, at stemningen blev bedre, fordi man i befolkningen nærede tillid og håb til f.eks. offentlige institutioner, den nye hærledelse, de nye rigskanslere, den uindskrænkede ubådskrig og forskellige andre succesmeldinger. Men disse forventninger blev ikke indfriet, tværtimod blev situationen værre i løbet af krigen. Man kan iagttage en tiltagende skuffelse, voksende mistillid og en udbredt forargelse i brede dele af befolkningen. Statsmagten kunne ikke lose de påtrængende problemer.

Krigen førte således til voksende indenrigspolitiske spændinger. Det har givet anledning til følgende hypotese, som kan forklare udviklingen. En regering kunne føre krig på trods af modviljen i store dele af samfundet, sålænge de sociale institutioner magtede at forsørge befolkningen og dermed udviste stabilitet. ${ }^{49}$ Netop det sociale system brød næsten fuldstændig sammen. Så længe befolkningens dagligdag var sikret og de sociale forhold stabile, ligeså længe var det muligt at holde den ulmende protest under kontrol. Men som en følge af de voldsomme misforhold blev befolkningen stadig mere aktiv.

Hertil kom et andet fænomen, som er med til at forklare forløbet nemlig moralens forfald. Først blev statsmagtens autoritet draget i tvivl, til sidst blev den ignoreret. I juli 1918 skrev det II. armékorps' generalkommando rammende: "Den lavineagtigt voksende tvangsøkonomis allerværste følge er den altoverstigende uærlighed og samvittighedsløshed, som har sat sig fast i hele folkesjælen. Nødvendigheden $i$ at måtte gå udenom love, nødvendigheden af at handle på det sorte marked eller at skaffe sig mad ved hjælp af ulovlige mani- 
pulationer eller tyverier, har ført til en almindeligt gældende ligegyldighed overfor overholdelsen af lovene, og den lader samvittighedens stemme forstumme. Der bliver stjålet og taget, hvor man kan få det. Plyndringer af hele togvogne foretaget af ansatte inklusive embedsmænd sker dagligt ... Man kan slet ikke stille vagter og poster nok op for at sikre ejendom, da man igen og igen må gøre den erfaring, at vagterne er med til at stjæle. Man finder på udspekulerede sikkerhedssystemer, når man sender varer afsted, alt er forgæves, der findes ingen sikkerhed læengere«. 50

Hvor langt var det tyske samfund nået, når myndighederne og befolkningen ikke engang kunne stole på statens fundament, de tyske embedsmænd? Skolelæreren H. Schröder fra Flensborg skrev i oktober 1917 i sin dagbog følgende: "Der er en, der hævder, at der efter krigen ikke vil findes noget ærligt menneske mere. Deri ligger der meget sandhed ... Strengt taget er det jo sådan, at man skal kunne klare sig med den foreskrevne ration, men dette bud bliver konstant overtrådt. Moralen lider meget. $\kappa^{51}$

Som en illustration for kriminalitetens omfang kan følgende grafiske afbildning være til hjælp.

Specielt den utilstrækkelige forsyningssituation og følgerne af denne bidrog $i$ allerhøjeste grad til at nedbryde den politiske og sociale orden. Kendsgerningen var, at statens institutioner ikke formåede at løse problemerne og kom til at fremstå som inkompetente i specielt forsyningsspørgsmålet, og dette medførte et tiltagende autoritetstab. Et tab der blev synligt allerede før november 1918. En synlig utilstrækkelighed, tiltagende krigslede og den politiske agita-

\section{Lovovertrædelser i Flensborg 1911-22}

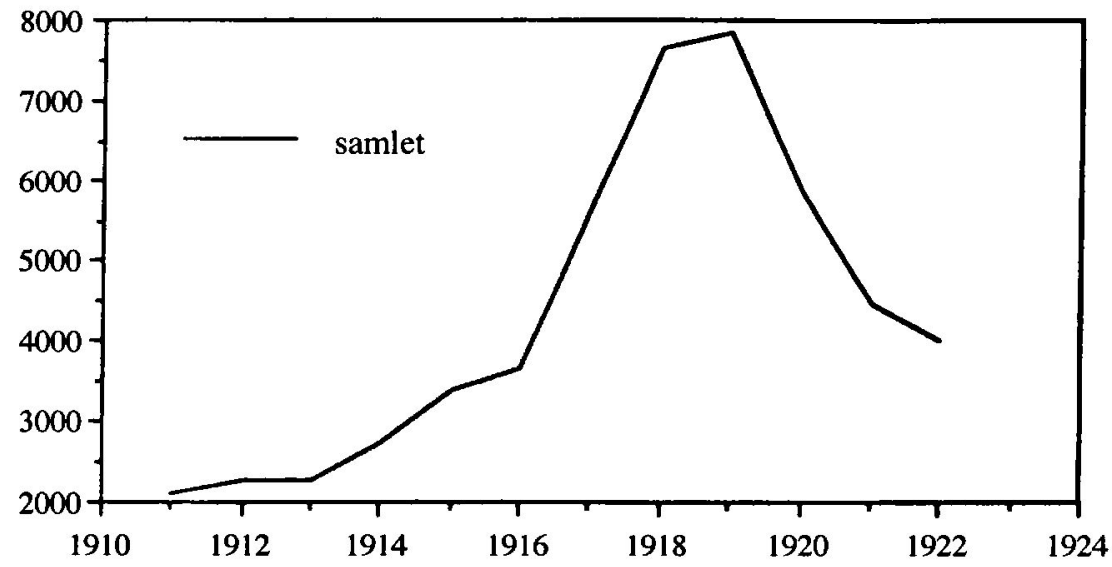

Fig. 1. 


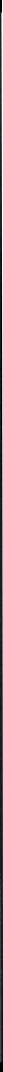

"Hjemmefronten" Flenshorgere pd Sondertorv kort for 1920. Foto i Dansk Centralbibliotek for Sydslesvig.

tion dannede grobund for revolutionen. Den udbredte uvilje overfor statsmagten var en vigtig forudsætning for, at matrosernes og soldaternes iværksatte revolution fik den store slagkraft. Mindst ligeså vigtigt var, at staten havde tabt 'prestige' over for både de besiddende og arbejdende klasser. Selvom dette tab havde forskellige årsager, pegede utilfredsheden på den samme kilde: staten. Det er da også interessant, at netop staten var målet for revolutionen og ikke den traditionelle klassemodstander.

Alle disse forhold er med til at forklare, at revolutionen brød ud, og at statssystemet faldt sammen i efteråret 1918.

NOTER

1. Klos 1995 s. $22 \mathrm{ff}$, især s. 29.

2. Kocka 1988 s. 60.

3. BM Freiburg RM 3/v 4670, 43671. 
4. BM Freiburg RM 3/v 4670 rapporten fra den 15.6 .1917$.

5. StJfdDR $1912 \mathrm{ff}$.

6. Ursachen und Folgen Dok. 112. Flyveblade fra spartakusgruppen med overskriften »Hunger« fra juni 1916 og dok. 113 Opråb fra fagforeningens generalkommision og SPD-ledelse den 25. juli 1916.

7. Dokumente aus geheimen Archiven s. XVII.

8. Feldman 1985 s. 271.

9. StJfdDR $1913 \mathrm{ff}$.

10. En stor del af strejkerne kunne ikke regsitreres og opgivelsen er derfor unøjagtig.

11. BM Freiburg RM 31/v 2383 29.7.1916. Urolighedernes talsmænd skulle arresteres eller sendes til skyttegravene.

12. BM Freiburg RM 31/v 2383 9.5.1917. Militæret kunne også vælge helt at tage kontrollen over virksomheden.

13. GStA Merseburg Rep. 89 H 2.2.1. Nr. 15266 bd. 3, 21.2.1918.

14. Ursachen und Folgen dok. 140 b. strejkekrav fra den 28. januar 1918 slutter med; Frieden, Freiheit und Brot - de fremsatte krav er overtaget fra aprilstrejken i 1917.

15. Ursachen und Folgen dok. $140 \mathrm{~g}$ se forordningen af den 1.2.1918.

16. Lucas $1976 \mathrm{s.}$ 152, se også Ursachen und Folgen dok. 140 i; Flugblatt des Vorstandes der USPD, februar 1918: "Wenn Ihr heute den Streik abgebrochen habt, ist das keine Beendigung des Kampfes. Schon rüstet $\mathrm{Ihr}$ zu neuen Kämpfen und zum Sieg«.

17. Möller 1994 s. 29.

18. Ver. Ber. 1911 s. 18 f., Ver. Ber. 1926 s. 21.

19. StA II C 128.

20. StA HS 101022.11 .1914 .

21. LA 3098305 28.4.1917.

22. LA 3098306 8.5.1917.

23. FIVZ 27.9.1915.

24. StA VIII B 51 Bd.1, Nicolai 1988 s. 174.

25. StA VIII B 51 Bd. 1 16.3.1917.

26. LA 30916602 8.3.1917.

27. LA 30916602 6.4.1917.

28. StA VIII B 51 Bd. $131.7 .17,10.4 .1917$.

29. LA 3091660226.3 .1917$.

30. FlA 17.4.1917, 21.4.1917, 30.5.1917.

31. StA VIII B 824.8 .1917 politiforvaltningen til magistraten vedr. brøduroligheder. StA HS 1010 13.7.1917.

32. StA VIII B 82 17.7.1917.

33. LA 3098306 . Forskelsbehandlingen af menige og officerer m.m. skabte stor utilfredshed, og stemningen blandt soldaterne gav anledning til bekymring.

34. LA 3098306 telegram 15.9.1917, GStA Merseburg Rep. 89 H 2.2.1 Nr. 16592 rapporten fra regeringspræsidenten i Slesvig til 'Kaiser und König' 25.10.1917.

35. LA 3098306 15.9.1917, se ligeledes StA HS 1010 14.9.1917, FlA 15.9.1917.

36. BM Freiburg RM 3/v 4698.

37. LA 309830630.1 .191$.

38. FLA 31.1.1918.

39. LA 3098306 4.2.1918.

40. Ver. Ber. 1926 s. 556.

41. StA II C 12824.11 .1914$.

42. FIVZ 27.9.1915, F1A 28.9.1915.

43. FIVZ 10.2.1916.

44. Interessante kilder vedr. utilfredsheden er de anonyme henvendelser til myndighederne. Se f.eks. StA VIII B 65. I GStA Merseburg Rep. 77 Ti. 3859 findes et langt anonymt brev med overskriften »Flensburger Zustände«. 
45. FIVZ 1.4.1913, 23.4.1913, 15.2.1916, F1A 8.5.1917.

46. LA 3098068.11 .1918$.

47. Windmann 1993 s. $44 \mathrm{f}$.

48. Klos 1992 s. 232 ff.

49. Hardach 1987 s. 185 overtager R. Renouvin: L'opinion publique et la guerre en 1917' Revue d'Histoire Moderne et Contemporaine 151968 s. 23.

50. BM Freiburg RM 3/v 7795 3.7.1918.

51. StA HS 1010 19.10.1917.

52. Ver.Ber. 1926 s. 169 ff., se yderligere Kocka 1988 s. 177 om den tiltagende kriminalitet, som et udtryk for statsmagtens fallit.

\section{LITTERATUR- OG KILDEOVERSIGT}

I oversigten er kun den citerede og i noterne anvendte litteratur fortegnet. Det samme galder for arkivmaterialet.

Dokumente aus geheimen Archiven 1914-18. Berichte des Berliner Polizeipräsidenten zur Stimmung und Lage der Bevölkerung in Berlin 1914-18. DDR 1987.

Feldman, Gerald D.: Armee, Industrie und Arbeiterschaft in Deutschland 1914 bis 1918, Bonn 1985.

Flensborg Avis 1913 ff. (FlA).

Flensburger Volkszeitung 1913 f. (FlVZ).

Hardach, Gerd: The First World War 1914-18, London 1987.

Klos, Michael: De tyske arbejderkvinder og verdenskrigen 1914-18, Arbejderhistorie 381992 s. 44 63.

Klos, Michael: De tyske arbejdere og 1. verdenskrig, Arbejderhistorie nr. 11995 s. 22-34.

Kocka, Jurgen: Klassengesellschaft im Krieg. Deutsche Sozialgeschichte 1914-18, Frankfurt 1988.

Lucas, Erhard: Zwei Formen von Radikalismus in der deutschen Arbeiterbewegung, Frankfurt a.M. 1976.

Möller, Horst: Weimar. Die unvollendete Demokratie, dtv 1994.

Nicolai, Britta: Die Lebensmittelversorgung in Flensburg 1914-18, Flensburg 1988.

Statistisches Jahrbuch für das Deutsche Reich 1912 ff. (StfdDR).

Ursachen und Folgen - Vom deutschen Zusammenbruch 1918 und 1945 bis zur staatlichen Neuordnung Deutschlands in der Gegenwart, bd. 1 udg. H. Michaelis m.fi., Berlin 1958.

Windmann, Horst: Die Flensburger SPD in der Zeit der Weimarer Republik: 1918-1923, i 125 Jahre $S P D$ in Flensburg, Flensburg 1993 s. 38-61.

\section{Stadtarchiv Flensburg (StA)}

\section{C Akten der Dienststellen}

128 Besondere maßnahmen in AnlaB des Krieges 1914-20.

V Wohlfahrtsverwaltung.

B 1078 Zentrale für Kriegsführsorge. Generalakten 1914-19.

VIII Kriegsbedingte Auftragssachen

B 51 Bd. 1-2 Schwer- und Schwerstarbeiter.

B 65 Anonyme Anzeigen 1917-19.

B 82 Unruhen betr. Brotversorgung 1917-18.

HS 1010 Heinrich Scbröder's Kriegstagebuch.

Bericht über die Verwaltung und den Stand der Gemeinde Angelegenheiten der Stadt Flensburg 1907-1911 (Ver. Ber. 1911).

Verwaltungsbericht der Stadt Flensburg 1911-1926 (Ver. Ber. 1926). 
Landesarchiv Schleswig-Holstein (LA)

309 Regierung zu Schleswig.

8305 Unruhen im Kriege 1916-18.

8306 Unruhen im Kriege 1917-19.

16602 Schwer und Schwerstarbeieter 1916-17.

Bundes- Militärarchiv Freiburg (BM Freiburg)

Reichs Marine Amt - RM

3/v 4670 Mobilmachung 1914 - Monatsberichte der Stellvertretenden Generalkommandos 1916-17.

3/v 4671 Mobilmachung 1914 - Monatsberichte der Stellvertretenden Generalkommandos 1918.

3/v 4698 Mobilmachung 1918 - Streiks.

3/v 7795 Mobilmachung 1914 - Monatsberichte über die wirtschaftliche und politische Lage MaiAugust 1918.

31/v 2383 Arbeiterunruhen.

\section{Geheimes Staatsarchiv Preußischer Kulturbesitz Merseburg} (GStA Merseburg)

Rep. 77 Tit. 3859 Die Verwaltung der Communal Angelegenheiten und der Anstellung, sowie die Personalien der Communalbeamten in der Stadt Flensburg 1887-1933.

Rep. 89 H 2.2.1. Nr. 15266 Die Sozialdemokratie und Anarchie Bd. 3.

Rep. 89 H 2.2.1. Nr. 16592 Die Zeitungsberichte des Regierungspräsidenten zu Schleswig. 